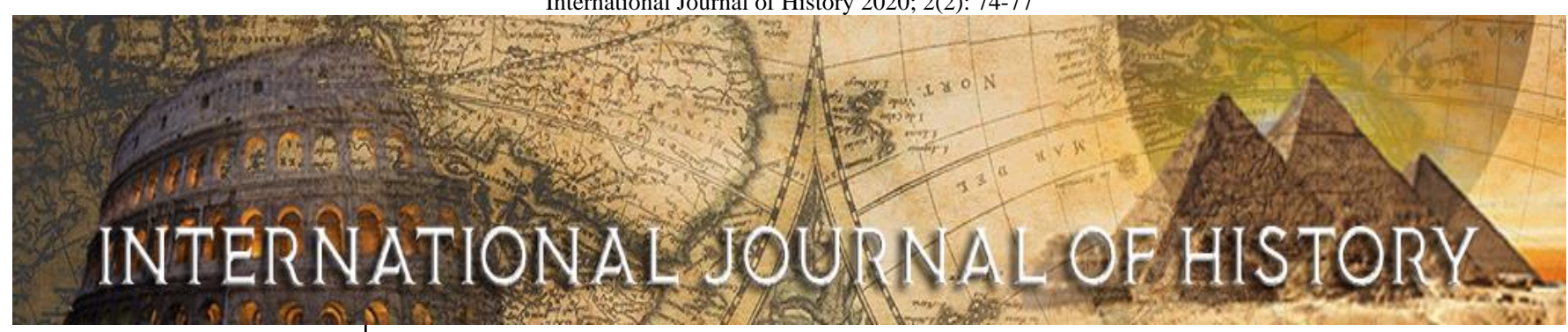

E-ISSN: 2706-9117 P-ISSN: 2706-9109 IJH 2020; 2(2): 74-77 Received: 16-05-2020 Accepted: 18-06-2020

Dr. Swati Kumari P.S.- L.N.M.U. Campus Dist- Darbhanga, Bihar, India
Corresponding Author: Dr. Swati Kumari P.S.- L.N.M.U. Campus Dist- Darbhanga, Bihar, India

\section{Some aspects of industries in modern mithila (With particular reference to Salt petre, Indigo, Jute and Sugarcane)}

\section{Dr. Swati Kumari}

DOI: https://doi.org/10.22271/27069109.2020.v2.i2b.46

\begin{abstract}
Mithila, the name itself reflects that this was the land of learning and meditation. It has been once a centre of education and was supposed to be almost the last word, so, far the religion, philosophy, logic, culture and economics was concerned ${ }^{2}$, Mithila had a charm of its own. The entire region of Nonh Bihar was known world over for its monopolising magnitude in this particular industry. The production of Indigo and the area under cultivation was nearly 100,00 areas at this Darbhanga contained the largest concern in India. We are concerned with has little potential for large and core sector industries. But that never means that a region not having basic minerals and alloys can never flourish industrially.
\end{abstract}

Keywords: Modern, Mithila, geographical, agricultural, Darbhanga, industrial, century, industry, mills

\section{Introduction}

Mithila, the name not merely suggests in area or the geographical region of entire North Bihar, but it reflects the culture, the tradition and the socio-economic heritage of the region. Mithila is the symbol of our glorious past ${ }^{[1]}$.

Mithila, the name itself reflects that this was the land of learning and meditation. It has been once a centre of education and was supposed to be almost the last word, so, far the religion, philosophy, logic, culture and economics was concerned ${ }^{[2]}$, Mithila had a charm of its own. The province that went by that name, has a glorious past in the cultural history of India, from the vedic time to the eighteenth century. We hear of it in the Mahabharata, and the Ramayana. Let its try to trace back the well established and affluent socio-economic structure of Mithila in the past and re-evaluate its present pitiable condition.

The geographical features of the region has given bouties to this region in terms of rich arriculture land, a network of rivers and rivulets to facilitatc irragation of the arable lands. The nature or soil is always closely correlated with the agricultural productivity ${ }^{[3]}$. North Bihar specially "Mithila" is often called the Grainry of India. Agriculture is not backbone of the regional economy. it almost represents the very philosophy of life in this region ${ }^{[4]}$. If agriculture is the basic need of humanity, industries are the backbone of an economy. Unless industrial advancement is achieved, an economy can never be classified as a developed one. Economic development of any region largely depends or the proper utilisation of resources. So why the Govt. of Bihar is not developing the agriculture base industry in this region?

The nation the economy or the economic organization has never been a strong point with the and people of Mithila, possibly comes epistemology, literature, music and moral art with little recorded account to fall back upon. What remains of its last glory is mere memory, which is often short lived and unsustainable; and nations being nations, are developed out of inadequate knowledge of the past and what is so superficialy visible at present ${ }^{[5]}$.

The systematic destruction of the traditional trade and industry by the colonial system is a well known phenomenon and Mithila was no exception to it. Decimated to the verge of extinction, the of Mithila, once rich in aspects of economic prcduction, organization and trade, was only little remembered ${ }^{[6]}$. Darbhanga (the heart of socio-political and cultural Mithila) lay on the great lines of Aryan immigration at the time when other parts of Bihar were outside the pale of Aryanism. According to a legend, Darbhanga formed a part of the territory in which the Vedilias settled on their migration from Punjab. 
The colonial period establishment it of British political supremacy over the greater part of India, it also marked the rise and development of several industries occupied a place of preminence. The period between 1756 and 1765 is characterized by a gradual transfer of loyalty from the native government to the English company. The process of this transfer which had started in 1757 by the British victory at Plessey came to a completion by the success of English at the battle of buxar in 1764. These two battles indeed accomplished significant political changes and also served to open new chapters in the history of industrial development tinder the company. In Bihar the first half of the eighteenth century was an era of economic stabilization [7]

In modern times Mithila region seems to have little to do with the industrial development ${ }^{[8]}$. But days were only in the recent past region used to almost monopolies the world market in a few times. Mithila's was a self sufficient economy in the olden days. Quite understandably the British Empire. We take them one by one.

\section{The Saltpeter Industry}

The Saltpeter and the Indigo industries were the two most prominent industries of this region in the past. As O-Mally Comment "The Bihar, which is the chief source of Saltpeter in India, the condition for the natural production of the compound approaches the theoretical ideal ${ }^{[9]}$. "Bihar, and to be more specific, North Bihar used to be the main supplier of this Saltpeter which was strategically so important for the British Empire, Lord Clive and Hastings introduced a system which provided for the control of manufacturing and sole of the Saltpeter by the agency of the company's servant. Thereafter, the production of Saltpeter continued to he governed and supervised by Britishers. Much before that the Europeans had established their factories in the region to purify the Saltpeter after purchasing it from the native producers called 'Noniya' and export it to the European markets ${ }^{[10]}$.

The earliest factories were established by the East India Company (Dutch) and East India Company (British) it Singhiya (Darbhanga). This industry flourished till the early $19^{\text {th }}$ century and the Europeans had complete control over it. But gradually the industry started to decline ${ }^{[11]}$. By 1847 there were only four factories left in Tirhut. Owned by the Europeans. Even during the period 1895-96 when this industry was on lapid decline.

Even during the period 1859-96 when this industry was on rapid decline. it was still bit enough in magnitude.

By the end of the first world war in 1918-19 this industry had completely perished. ${ }^{\mathbf{1 2}}$ Easy availability of rock-salt. persian-salt and the sea-salt completely substituted the Saltpeter as much cheaper and better substitutes. 'Noniyas' the poor hardy people. who were mone or less exclusively engaged in the Saltpeter industry, had to take refuge in some other occupation. without knowing the fact that they, once upon the time used to he the producer of this specific item which had helped the British Empire to he the world-ruler [13].

\section{The Indigo Industry}

The story of Indigo industry is more pathetically instructive than that of almost any other Indian Agricultural or industrial substance ${ }^{[14]}$. The entire region of Nonh Bihar was known world over for its monopolising magnitude in this particular industry ${ }^{[15]}$. This industry had led the region to the crest of commercialization and hod not only brought the British entire preneurs some great fortunes but also proved ultimately. to ha the womb where the embryo of freedom movement took a fermidable shape ${ }^{[16]}$. Fifty five year latter, when the industry finally shifted Lower Bengal to North Bihar, Mahatma Gandhi and Dr. Rajendra Prasad were to take up the cause of the miserable Indigo-riots at a timer when the cheaper chemical dyes struck a death blow to the industry and its owners - The planters who acted as te agents of the colonical exploitation ${ }^{[17]}$.

The Indigo-plantation was not introduced by the European, as a few scholars claim. The indigo cultivation was known to Indians front ancient times, of which several references can be had from the ancient, treats and archaeological evidences. Europeans did of course change the cultivation manner and processing techniques for better and more profitable outworn. The demand for Indian Indigo early in the $18^{\text {th }}$ century British markets fell off and in 1727 it was omitted from the list of the companies investments. The first contract for the supply of Indigo was made with one $\mathrm{Mr}$. Princep in the year $1779{ }^{[18]}$. Gradually there was a mushroom growth of the investors in the industry and soon Lord Carniwalles had to take notice of it. Once given enough oppurtunity, the Indigo industry expanded by leaps and bounds. In reort submitted in 1810, Europe, that 30,000 to 50,000 souls received their principal support from the factories and that on the average, each factory disbursed from Rs. 25,000 to Rs 30,000 per minim in hard cash to the laborious and cultivators for some miles around ${ }^{[19]}$.

By 1874 there were altogether 126 factories and outworks engaged in the production of Indigo and the area under cultivation was nearly 100,00 areas ${ }^{[20]}$. At this Darbhanga contained the largest concern in India, that was in Pandaul which. with its outwork comprised an area of more than 300 square-miles. Hots ever, it way subsequently split-up, the northern being purchased by the Maharaja of Darbhanga. who abandoned the cultivation of Indigo in them in the closing year of $19^{\text {th }}$ century ${ }^{[21]}$. But the problems and difficulties had stained creeping-up much before. The price obtained from indigo is barely sufficient to cover the cost production and many factores are either closing altogether or are reducing the area cultivated with Indigo, grossing in its place, sugar, cotton and other country crops ${ }^{[22]}$.

From the year $1874-75$ till the end of the $19^{\text {th }}$ century, Pandaul was the biggest-center of Indigo-production [23]. Likewise in Purnea, Champaran, North Bhagalpur, and North Monghyr (Begusarai), there were several indigo factories flourishing and earning high, profits. In Purnea district there were 77 Indigo factories and average animal production was not less than 4019 maunds. By the end of year 1876 there still remained 59 Indigo-facrorics ${ }^{[24]}$.

The cheap Indigo-dye introduced in Gemany in 1896 had given a setback to the Indigo-Industry of Tirhut and planters fell back to Tobacco and Sugar plantation.

The year 1877 was a critical period in the history of Indigo planters in Bihar also in Mithila. Thus, this industry come to a rather abrupt end. Nevertheless this illuminous industry of North Bihar, which had virtually monopolised the world market in its hay days had still enough virtues left to lead the nation in the struggle for independence vide it final funeral procession ${ }^{[25]}$. 


\section{Sugar Industry}

Sugar is the most important industry depending on agriculture. Mithila region is well known for irs sugarcane production.

The soil of the region is also suited to it. Champaran, Muzaffarpur, Purnea and Darbhanga districts all of them produce huge amount of sugarcane, Initially there used to he the Gur-Khandasari industry. The sugar industry was pioneered in this region by Dutch-men and since then this industry prospered quite fairly till the $1^{\text {st }}$ half of the $19^{\text {th }}$ century. Huge quantity of sugarcane was grown in this area. Many of the sugar factories were all, closed down or converted into Indigo factories. The trend continued almost till the end of the first decade of the present century, when ultimately the sugar industry glory. In Darbhanga district it was concentritod in Madhubani Sub-division, where by $1895-96$ only thirty two refinoriess were, left and only 43,000 maunds of sugar.

The actual credit for re-organizing and revitalising the sugar industry in Mithilia region should go to the 'India Development company' (which in 1900-01) purchased the ottor (Atahar) and Agrial Indio factories in Muzaffarpur to grow sugarcane. In. Mithila region there were as many as fifteen big sugar factories by the year 1950 .

A number of legislations to safeguarded the interests of cone growers and the factory management ${ }^{[26]}$. But the ever fluctuating price-policy the controlling and decontrolling sugar-policy of the central government, tough competition from the cane, all of it tagged together to a miserable infrastructure in an extremely rapidly changing economic scenario, led to the gradual decline of this industry in this region. Though still not irreversibly risk, most of the units of sugar production of the region are virtually on the verge of collapse, waiting, and happing against the hope, that something possible would be done for them ${ }^{[27]}$.

\section{Jute Industry}

Jute is one of the important commercial crops in India. The industry flourished soon in dated the $23^{\text {rd }}$ Dec. 1794 in Bengal including the North Bihar (Mithila) region. In Mithila Jute is grown in the district of Purnea, Saharsa, Katihar, Muzaffarpur, Darbhanga. The only district growing it on a large extent was purnea $86 \%$ of the total cultivation set, grown in this district ${ }^{[32]}$. Previously there were three large Jute mills in this region

(i) Katihar Jute Mills Ltd. Katihar, (ii) Rameshwar Jute Mills Company Ltd. Muktapur and (iii) Motilat Chamariya Jute Mills, Katihar one of the prime reasons of these industries being based in this region apart of easy availability of Jute was is cheap and plentiful availability of labourers. ${ }^{29}$

The Rameswar Jute Mills com. Ltd. Maktapur was the only It rge Jute Mill in Darbhanga district. It was established in the year 1926 and was converted into a limited concern in the year $1935^{[30]}$ The above mentioned three mills of Jute consist of about 1000 looms. The production in 1956 was nearly 23 tons. Darbhanga unit there were 1767 workers and in Katihar units 4247 workers were employed. ${ }^{31}$ There were 28 similar units also which in all employed about 643 persons in only Purnea district. Purnea production $90 \%$ of the total production ${ }^{[32]}$.

6. Total in Mithilatichal (North Bihar) $=\mathbf{4 0 5 0 0 0}$ acres. Apart of these conventional and traditional in Justries, there were few relatively new industries in the region, such as. Automobile-workshop industry, Bakeries, Brickmanufacturing industry, Musical Instrument Industry, Chemical Industry, Cold Storage, Ice-Cream Industry, Engineering-Work ship, Printing Prer Slate and Pencil Industry, Flour- Mills etc. But to be less hypothetical and more honest one should see that there are a number of problems associated with these small-scale industries. An important before of the small scale units is that good percentage of them may be bogus. The all India report on census of small scale industrial units concludes "The difference between the figures conveying cumulative totals and working units is the high incidence of sickness. Many of them close down for went of working capital." This seems to be absolutely true for the region.

In is quite evident from the government of India's industrial policy 1977 puts it "It is the policy of the govt. that what can be produced by small scale and cottage industries must only be so produced. It we look into the matter with greater perspective, we find that the main features of the industries of this region has to predominantly he based on agriculture. The region, We are concerned with has little potential for large and core sector industries. But that never means that a region not having basic minerals and alloys can never flourish industrially. There are as we have seen a number of avenues in which industries can develop, not only to elnrich the region itself but also to uplift the state and the national economy consequently. We have got examples of Japan and the Asian tigers, where economy flourished primarily vide agriculture and small unit industries. Mithila has enough to offer, provided keen eyes of investigation, deed incentive of industrialization and proper planning backed up by sound govt. policy are properly, programmed. Many new and profitable industries can come up. The need is to initiate the development process through using all types/kinds of available resources in right perspective.

\section{References}

1. Mishra VK. (Cultural Heritage of Mithill)

2. Dr. Karnath KS. Ibid - Forward, 50

3. Ibid, 25

4. Mishra VK. Cultural Heritage of Mithila, 354

5. Dr. Jha SK, Jhd B. The Economic Heritage of Mithila.

6. Ibid, 47.

7. Dr. Dutta KK. The comprehensive History of Bihar. -3, I

8. Statement- Industrial policy, 1877

9. Maley O. Dist. Gazetteer Darbhanga, 1907.

10. Chaudhary PC. Roy. Cit. P-220.

11. Ibid, 220

12. Hunter WW Op. Cit, 129

13. Dr. Datta KK. The comprehensive History of Bihar, I, 3

14. Champaran Gazetteer; 103, Muzaffarpur Gazetteer, P.P-91, 92 \& Darbhanga Gazetteer, 92

15. Ibid. Ibid, Ibid, P-103, P-94 P-92.

16. Gadgil, op. Cit, 264.

17. Mittal SK. Peasantry uprising and Mahatma Gandhi in North Bihar, 2

18. Indigo commission Retort; Micro film reel No-76. also Neel Darpan (Ed. Sudhi Pradhan, Calcutta, P-VI)

19. W.W. Hunter; op. Cit, XIII, 99

20. Singh SN. History off Tirbut, 238-39

21. Ibid, 240

22. Wilson Minder: History of Bihar, 311 
23. Ibid, 760

24. O. Malley op. Cit. P.P-104-05 also Ref. P C.R.C; Op, Cit, 761

25. Malley O. Purnea District Gazetteer, 127-30

26. Ghosh HH. Sugar in India. Its cultivation, Manufacturing \& Trade, 188-20.

27. Pt. Parmeshwar Jha Mithila Tatwa Vimarsh, 1949, 164.

28. The Bihar Gazetteer, Extracts, 1950

29. PCRC. Op. Cit. 228.

30. Dutta KK. The comprehensive history of Bihar Part-I, III

31. Chandel RC, Jute RC. Industry of Bihar P-61

32. Economic Survey of Bihar, I, 211. 